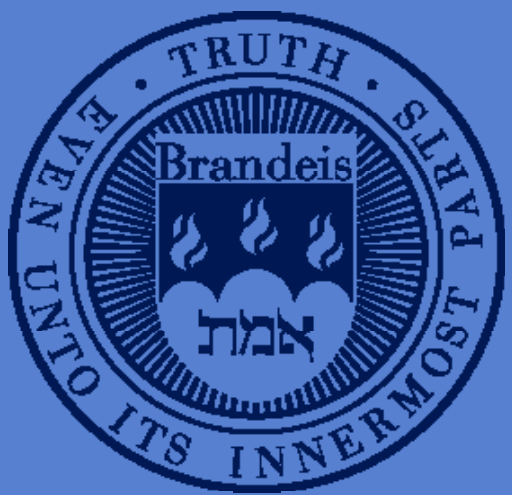

Foreign Technology Acquisition and Changes in the Real Exchange Rate

Roberto Alvarez, University of Chile

Ricardo A. López, Economics Department, Brandeis University

Working Paper Series 


\title{
FOREIGN TECHNOLOGY ACQUISITION AND CHANGES IN THE REAL EXCHANGE RATE ${ }^{\dagger}$
}

\author{
Roberto Alvarez* ANd Ricardo A. López**
}

(OCTOBER 2014)

\begin{abstract}
This paper uses plant-level data from the manufacturing sector of Chile to investigate how changes in the real exchange rate affect the decision to purchase foreign technologies through licensing. Theoretically, a real depreciation has an ambiguous effect on foreign technology adoption. On the one hand, a real depreciation makes exports more competitive, and since exporters tend to adopt and use more advanced technologies, we should observe a higher propensity to import technologies among them. On the other hand, a real depreciation can also make imports of technology relatively more expensive. Thus, this question must be examined empirically. The empirical analysis shows that a real depreciation significantly increases the probability of using foreign technology licenses for plants that export and for plants in the intermediate range of the size and productivity distribution.
\end{abstract}

\footnotetext{
${ }^{\dagger}$ We would like to thank two anonymous referees and participants at the 7th Workshop of the International Study Group on Exports and Productivity (ISGEP) held at the Royal Institute of Technology, Stockholm, Sweden, on September 27-28, 2012 for helpful comments and suggestions. We also thank Pedro Roje for excellent research assistance. Alvarez also thanks the Millennium Science Initiative (Project NS 100017 'Centro Intelis') for their financial support.

${ }^{*}$ University of Chile, Santiago, Chile.

** International Business School, Brandeis University, Waltham, MA, USA.
} 


\section{INTRODUCTION}

Technological change is the main source of productivity growth in the long run for both developed and developing countries. A central element of technological change is innovation, which allows countries to improve their technologies as well as the quality and the range of products they produce. The sources of innovation among nations, however, differ according to the countries' level of development. While developed countries innovate mostly through investments in R\&D, developing countries acquire new technologies and new product designs by copying or purchasing them from industrial countries. This is because it is relatively easier to adopt and adapt a foreign technology than to create an entirely new technology. ${ }^{1}$ One way to obtain new and more advanced technologies is through foreign technology licensing agreements, in which the owner of a technology, the licensor, authorizes the use of its technology to the buyer, the licensee, in exchange for license fees or royalty payments.

The purpose of this paper is to study the effects of a significant depreciation of the real exchange rate (RER) that occurred in Chile between 1998 and 2002 on the probability of foreign technology licensing among Chilean manufacturing plants. In theory, a real depreciation has an ambiguous effect on the decision to purchase foreign technologies. A real depreciation makes exporting firms more competitive and therefore more likely to use foreign technologies. Several studies argue that increases in export competitiveness may induce some firms to adopt foreign technologies because they may need to improve the quality of the products they produce for export markets (López, 2009; Lileeva and Trefler, 2010; Bustos, 2011). Increases in export competitiveness may also induce non-exporting firms to upgrade their technologies if, for example, they provide intermediate inputs or services to exporting firms. Becoming a licensee, however, requires finding and contacting the owner of a technology, or a product, willing to license its knowledge in exchange for license fees or royalty payments. This implies that technology licensing is costly and that relatively larger and more productive firms may be more likely to

\footnotetext{
${ }^{1}$ According to Westphal (1982), importing a technology does not require complete mastery of it, as it would be the case of creating a new technology.
} 
use foreign technology licenses. A real depreciation, however, could also make imports of technology, and related components, such as machinery and equipment, relatively more expensive which may decrease the propensity to import technologies. Since the theory, a priori, is not clear about the effect of changes in the RER on foreign technology acquisition, this question must be investigated empirically.

This issue is important for several reasons. First of all, licensing is more relevant than ever as a source of technologies. According to the World Bank's World Development Indicators, payments in royalties and license fees worldwide increased from about \$40 million in 1960 to about 200 billion in 2010/2011. Part of this increase may be explained by the increasing protection of intellectual property rights around the world, which likely discourages copying in favor of licensing. ${ }^{2}$ Second, as the globalization process has deepened, countries are more interconnected as ever with each other, which makes movements in exchange rates potentially important for decisions such as investment and technology adoption. Third, if firms are more likely to import technologies during periods of real depreciation than in appreciation times, then governments should consider the effect of RER fluctuations on technology adoption when designing policies that promote technology transfer.

This paper is related to at least two strands of literature. The first corresponds to the literature that examines the determinants of foreign technology adoption and its impact on firms' performance using micro data at the level of the firm or plant. Studies such as Giannitsis (1991), Montalvo and Yafeh (1994), Kokko and Blomström (1995), Katrak (1997), Vishwasrao and Bosshardt (2001), and Kiyota and Okazaki (2005) provide evidence on the characteristics of licensees and the role of these characteristics in foreign technology adoption. While these studies significantly contribute to understanding foreign technology adoption they do not examine how changes in RERs may affect the decision to adopt a foreign technology. The second strand of literature examines the effect of RER fluctuations on firm-level outcomes such as export propensity and export intensity (Bernard and Jensen, 2004; Greenaway, et al.,

\footnotetext{
${ }^{2}$ As intellectual property rights become stronger, it is possible that licensing becomes relatively more attractive than exports and FDI as a channel for technology transfer (Smith, 2001; Hoekman and Javorcik, 2006).
} 
2010a, 2010b, 2012; Fitzgerald and Haller, 2012), investment (Kandilov and Leblebicioğlu, 2011), and skill upgrading (Alvarez and López, 2009). The effect of RER changes on foreign technology adoption, however, has not been examined. Thus, our paper complements and extends the existing literature by linking these two strands of literature.

The empirical analysis uses a panel of manufacturing plants, and takes advantage of dramatic changes in the aggregate RER in Chile during 1992 and 2002, which can be considered an exogenous shock from the point of view of an individual plant. We use these changes as a quasi-experiment to examine if the significant real depreciation of the currency affected the decision to import foreign technologies through licenses, and whether the effect differed across plants and industries with different characteristics. The empirical analysis shows that an increase in the rate of change of the RER increases the probability of acquiring foreign technologies through licensing agreements on plants that export. We also find that real exchange rate depreciations increase the probability of using foreign technology licenses in more productive and larger plants, but that the effect is not linear: as productivity and size increase, a real depreciation induces technology adoption but the effect is smaller for the most productive and largest plants. These results are consistent with recent evidence by Bustos (2001) for Argentinean firms, who shows positive effects of decreases in foreign tariffs on technology upgrading and that the effects are higher in the intermediate range of firm-size (productivity) distribution. ${ }^{3}$

The paper is organized as follows. The next section describes the dataset used in the analysis and documents licensing activity in Chile. The third section describes and explains the methodology, while the fourth section presents and discusses the results. Section five presents a set of robustness checks and extensions, and section six concludes.

\footnotetext{
${ }^{3}$ In her empirical analysis for Argentina, Bustos uses a dummy by size quartiles as proxy of productivity and focuses on a reduction in Brazilian tariffs.
} 


\section{DATA AND BASIC PATTERNS}

Chile spends an insignificant fraction of its GDP on R\&D activities. As we can see in Figure 1 for the period 2007-2008, the expenditure on R\&D in Chile was only $0.34 \%$ of the GDP, a number that is considerable lower than that of the OECD countries (2.32\%) and the U.S. (2.77\%). Chile spends in R\&D even less than other Latin American countries of similar level of development, such as Mexico (0.38\%) and Argentina (0.51\%).

These numbers suggest that invention and innovation activities are not significant in the case of Chile, and that the country has to rely on foreign licenses to obtain technologies and new product designs. This is confirmed in Table 1 which shows the payments on royalties and license fees as a percentage of the GDP for Chile, the Latin American region, and the OECD. As we can see in the table, the amount spent on royalties and license fees in Chile increased from $0.10 \%$ of the GDP in $1975-1980$ to $0.30 \%$ in the period 2001-2010, a number that is in line with the average for the OECD countries. The table shows that the payments in licenses also increased in the Latin American region as well as in the OECD. Although the magnitude of the increase in license payments in Chile is larger than the increase in Latin America, it is lower than the increase observed in the OECD.

The empirical analysis uses plant-level data from the manufacturing sector of Chile for the period 1992-2002. The data come from the National Annual Industrial Survey (carried out by the National Institute of Statistics of Chile), which covers all manufacturing plants with 10 or more workers. The survey contains information on plants' output, value added, sales, employment, export status, spending on foreign technology licenses, and industry affiliation. All monetary variables are expressed in constant prices of year 1996 using 3-digit level price deflators.

The number of plants in the sample is a little less than 4,000 plants on average each year. The percentage of plants purchasing foreign technology licenses is about $6 \%$ and it has not changed significantly over time. There are important differences between plants that invest in licenses and those that do not. While $20 \%$ of those plants that do not purchase licenses are exporters, more than $50 \%$ of 
plants that invest in foreign technologies are exporters. In term of size, plants that purchase licenses are larger. They employ, on average, 249 workers, while plants that do not invest in foreign technologies hire about 73 workers (Table 2).

\section{Methodology}

The empirical analysis exploits the large swings in the RER between 1992 and 2002. Figure 2 shows the evolution of the monthly RER between 1992 and 2003. Since we define the RER as the ratio between the international price and the domestic price of a basket of goods, expressed in the same currency, an increase in the RER represents a real depreciation of the Chilean currency. ${ }^{4}$ As we can see in the graph, there are two well-defined periods of significant changes in the RER. The first period, 1992-1997, was characterized by a continuous real exchange rate appreciation of the Chilean currency. Between January of 1992 and December of 1997 the RER decreased (appreciated) by almost 26\%. The second period, 1998-2002, showed a significant real depreciation. Starting on January of 1998 the RER began a slow but continuous increase. Compared to the level of January 1998, the RER had increased (depreciated) by more than $28 \%$ by the end of 2002 .

Since the dramatic changes in the aggregate RER are exogenous from the point of view of an individual Chilean plant, we can use these series of changes as a quasi-experiment and examine if the significant real depreciation affected the decision to import foreign technologies through licenses. The main econometric issue that needs to be addressed is the potential influence of unobserved heterogeneity. Some firms may have managers more willing or more capable to import foreign technologies and may therefore be more likely to use foreign technology licenses. In a similar way, due to the nature of the

\footnotetext{
${ }^{4}$ The index of international prices used in the calculation of the RER is constructed as a geometric average of the producer price index (in some cases, the consumer price index is used), expressed in U.S. dollars, of the main trade partners of Chile, where the weights are the share of each trade partner in Chile's total amount of international trade. These weights are calculated and updated every year.
} 
products produced, some sectors may be more likely to use licenses to import their technologies. These issues are not easy to address with traditional probability models such as probit or logit. Thus, we use a linear probability model with plant fixed effects, as follows:

$$
\operatorname{Pr}\left(L_{i j t}=1\right)=\alpha+\gamma L_{i j t-1}+\beta Z_{i j t-1}+\lambda \Delta \log \left(R E R_{t-\tau}\right) * Z_{i j t-1}+\mu_{i}+\delta_{t}+\epsilon_{i j t},
$$

where $L_{i j t}$ is an indicator variable equal to 1 if plant $i$ operating in sector $j$ is a licensee, i.e., it reported payments in foreign technology licenses and foreign technical assistance at time $t, \Delta \log \left(R E R_{t-\tau}\right)$ is the change in the log of the RER between years $t$ and $t-\tau$. The empirical analysis considers 5-year and 3-year changes in the RER ( $\tau=5$ and $\tau=3$ ). The reason for using changes over a relatively long period of time instead of short-run changes (for example, 1-year changes) is that investing in a foreign technology is likely to involve sunk costs, which suggests that firms may not have an incentive to invest if they perceive that the changes in the RER are temporary or short lived.

The vector $Z_{i j t-1}$ is a set of plant characteristics including productivity (value added per worker), and its squared term, export status, and size (number of employees) and size squared. ${ }^{5}$ These variables are included because previous studies have documented a positive correlation between foreign technology licensing and variables such as size (e.g., Mytelka, 1978; Giannitsis, 1991; Montalvo and Yafeh, 1994; Vishwasrao and Bosshardt, 2001), productivity and capital accumulation (e.g., Alvarez, et al. 2002; Kiyota and Okazaki, 2005; Yasar and Paul, 2007), and export orientation (e.g., Alvarez and López, 2005). Finally, $\mu_{i}$ is a set of plant fixed effects that attempt to control for unobserved characteristics at the plant level, and $\delta_{t}$ corresponds to a vector of year fixed effects.

\footnotetext{
${ }^{5}$ The inclusion of square terms for productivity and size, attempts to investigate if the effect of changes in RER on licenses acquisition is non-linear on those two variables. As explained earlier, this possibility has been shown theoretically and empirically by Bustos (2011), who finds that a decrease in foreign tariffs induces technology adoption for firms in the middle range of the productivity distribution for the case of Argentina.
} 
Note the estimation of equation (1) requires information only on whether the plant reports any spending on foreign technology licenses rather than information on the actual amount of royalties and license fees paid. Although our dataset contains information on royalties and license fees, we opted for not using this variable as it may not reflect the true value of the technology being transferred. As explained by Pack (2006), royalties and license fees are more likely to reflect the outcome of a bargaining process between the licensee and the licensor. Moreover, even if licenses expenditures are well recorded, they may underestimate the impact of technology transfer, since not all contacts with foreign suppliers are necessarily reflected in the license fees (Pack, 2006).

The parameter of interest is $\lambda$, the estimate for the interaction term between the set of plant characteristics and the change in the RER. The sign and magnitude of the estimated parameter will allow us to find out if larger, more productive plants, and those that export are more, or less, likely to purchase foreign technologies during times of RER depreciation.

We also estimate an extension of (1) that includes interaction terms between the change in the RER and two industry-level characteristics: the degree of external financial needs, and an index of revealed comparative advantage. By including a measure of external financial needs we aim to investigate if changes in the RER are more or less likely to affect foreign technology acquisition in sectors that are more financially constrained. It is possible that plants operating in sectors more dependent on external finance are more likely to purchase foreign technologies in response to a large depreciation. In this case, the depreciation may reduce the burden of being financially constrained. But a real depreciation may increase the probability of purchasing foreign technologies if the sector is less dependent on external finance, suggesting that a real depreciation may complement the low financial needs of the sector. The measure of comparative advantage tries to capture if real depreciations affect technology adoption relatively more on firms that operate in comparative advantage sectors. It can be argued that a real depreciation is likely to increase technology licensing in plants operating in sectors in which the country has a comparative advantage, but given that Chile is a relatively natural resource abundant country, it is expected that comparative advantage sectors are those producing natural resource intensive products, 
which may not be intensive in the use of foreign technologies. If this is the case, then the effect may be negative.

These two variables are included as follows:

$$
\begin{aligned}
\operatorname{Pr}\left(L_{i j t}=1\right)= & \alpha+\beta Z_{i j t-1}+\lambda \Delta \log \left(R E R_{t-\tau}\right) * Z_{i j t-1}+\theta_{1} \Delta \log \left(R E R_{t-\tau}\right) * E F D_{j} \\
& +\theta_{2} \Delta \log \left(R E R_{t-\tau}\right) * C A_{j}+\mu_{i}+\delta_{t}+\epsilon_{i j t}
\end{aligned}
$$

where $E F D_{j}$ is a variable measuring industry-specific differences in financial needs (external financial dependence), while $C A_{j}$ measures differences in comparative advantage among sectors. The variable measuring industry-specific differences in financial needs is taken from Rajan and Zingales (1998), and it is defined as the fraction of capital expenditures not financed with cash flow operations. It is calculated for the median U.S. firm at the 3-digit ISIC sector level. Rajan and Zingales (1998) argue that this variable is a useful measure at the industry level for other countries as well, by assuming that this indicator reflects technological factors that may explain why some industries rely more on external finance than others. They argue that these technological differences persist across countries. The variable of comparative advantage corresponds to the average of the Balassa index of revealed comparative advantage (RCA) for the period 1992-1997. The Balassa index is calculated as $R C A_{j t}=\left[\left(X_{j t}^{\text {Chile }} / X_{t}^{\text {Chile }}\right) / X_{j t}^{\text {World }} / X_{t}^{\text {World }}\right]$, where $X_{i t}^{\text {Chile }}$ is the value of Chilean exports of sector $j$ in year $t$, $X_{t}^{\text {Chile }}$ is the total value of exports of Chile in year $t, X_{j t}^{\text {World }}$ is the value of world exports of sector $j$ in year $t$, and $X_{t}^{\text {World }}$ corresponds to total world exports in year $t$.

Table 3 presents summary statistics for all the variables included in the estimation. The sample average of licensees is $6 \%$ while more than $20 \%$ of the plants are exporters. There are also significant differences across plants in terms of size and labor productivity. Regarding industry-level variables, 
financial external dependence ranges from -0.15 (less dependent) to 1.14 (more dependent), while the average value for the Balassa index fluctuates between 0.023 and 18.27.

\section{Results}

Table 4 presents the main results of estimating equations (1) and (2) using 5-year and 3-year changes in the RER. Columns (1) and (2) measure the change in the RER using 5-year intervals, while columns (3) and (4) use 3-year changes. First of all, we can see that the estimate for having used licenses during the previous year is positive and statistically significant across all the specifications, indicating that there exist sunk costs of adopting foreign technologies, which may produce persistence in the use of technology licenses. Having purchased licenses in the previous year increases the probability of licensing by about $12 \%$. This number, which suggests a relatively low level of persistence, may be biased downward due to the inclusion of plant fixed effects. Alternative specifications, based on OLS and a Probit model, give estimates for the lag of the dependent variable of about $40 \%-50 \%$.

Looking across columns in Table 4, we see that there are heterogeneous effects of changes in the RER across plants. As seen in the table, the estimates for the interaction term between the 5-year change in the RER and the export dummy is positive and statistically significant regardless of the specification, indicating that a larger change in the RER (a larger real depreciation) increases the probability that plants that export will use foreign licenses. We also observe that the effect of an increase in the change in the RER is positive as productivity increases but that the effect starts to decrease after a certain threshold. Similar pattern is observed for the interactions with size, suggesting that a real depreciation has a nonmonotonic effect on technology adoption in terms of productivity and size.

Columns (2) and (4) show the results of estimating equation (2), which include interaction terms between the change in the RER and the two industry characteristics: the degree of external financial dependence and the variable measuring comparative advantage. The estimates for both the interaction 
between the change in the RER and external financial dependence and the interaction between changes in RER and the variable of revealed comparative advantage are not statistically significant

Overall, our results suggest that real depreciations increase the probability of acquiring foreign technologies through licenses for plants that export and for larger and more productive plants, although the effect is not linear.

\section{Robustness CHECKS AND EXTENSIONS}

We have performed a number of robustness checks to verify the validity of our main results. The first exercise attempts to control for the potential spillover effect from plants that use licenses and from plants with foreign ownership. It is possible, for example, that some plants start using foreign technology licenses when the number of licensees, or the number of foreign-owned plants, increases. This could be due to demonstration effects or information spillover effects. In order to control for the potential effect of licensing activity and the presence of foreign companies in the sector, we calculate the share of plants using licenses and the share of plants with foreign ownership in the total number of plants, the total value added, and the total employment in each 3-digit ISIC sector and year.

Table 5 presents the results when these additional control variables, lagged one year, are included. Columns (1)-(3) show the results with the 5-year changes in the RER, while columns (4)-(6) present the results with the 3-year changes. Columns (1) and (4) include the share of licensees and foreign-owned plants in the total number of plants, columns (2) and (5) include the share of these plants in value added, while columns (3) and (6) use their share in the employment of the sector. As we can see, an increase in licensing activity of the sector significantly increases the probability that a plant will use foreign technology licenses. ${ }^{6}$ This is regardless of the way licensing activity is measured. The presence of foreign-owned plants, on the other hand, does not have any significant effect on the probability of

\footnotetext{
${ }^{6}$ This is consistent with the findings of Montalvo and Yafeh (1994) for Japan.
} 
licensing. The results seem to suggest the existence of positive horizontal spillover effects from licensing activity, although more work is needed to confirm this.

The estimates for the change in the RER and its interaction with productivity, size and the export dummy remain similar to the ones without the additional controls in Table 4 . We continue observing that an increase in the change in the RER increases the probability of using foreign licenses for plants that export, and in more productive and larger plants, but again the effect of productivity and size is not linear.

Next, we extend the analysis to examine the potential effect of import tariffs. It is possible that the supplier of the foreign technology sells the technology in a package, including both technological components and non-technological components such as intermediate inputs. ${ }^{7}$ If this is the case, a higher level of domestic import tariffs should have a negative effect on the probability of using foreign licenses. In addition, changes in the RER may not have a significant effect if tariffs are relatively high. Thus, we introduce the tariff rate charged by Chile to imported goods in each 3-digit sector and also its interaction with the change in the RER. We use the import-weighted effectively applied tariff from the TRAINS dataset. ${ }^{8}$ In addition, we also include in some specifications the import-weighted tariff applied by the rest of the world on Chilean products at the 3-digit level. Lower foreign tariffs may induce firms to export more and this may induce foreign technology adoption.

Table 6 present the results when including import tariffs. Columns (1) and (3) include the domestic import tariff, while columns (2) and (4) also include the foreign tariff rate applied on Chilean products. We have also included interaction terms between the change in the RER and the two tariffs rates to see if the level of tariffs in the sector affects the impact of real depreciations on the probability of using licensing. As seen in the table, the estimates for domestic tariffs and their interactions with the change in

\footnotetext{
${ }^{7}$ This is indeed common. See, for instance, Dahlman and Westphal (1982), Bhattacharya (1985), and Arora (1996).

${ }^{8}$ We also estimate regressions using the simple average tariff but the results are similar. The use of a simple average tariff is potentially problematic as it treats all commodities identically. The simple average is also sensitive to changes in goods classification in the tariff code (Anderson and Neary, 2005, chapter 1).
} 
the RER are not statistically significant, suggesting that the level of Chilean tariffs do not affect the effect of depreciations on foreign technology licensing. This may be due to the fact that Chilean tariffs are relatively low and similar across industries. During the period under analysis, the average import tariff across industries was $8.4 \%$ and the standard deviation was only $1.4 \%$. For the case of foreign tariffs, the results are slightly different. Even though the estimate for foreign tariffs is not significant across columns, the interaction between foreign tariffs and the change in the RER is positive and statistically significant regardless of whether we measure the change in the RER using 5-year or 3-year intervals. Thus, a real depreciation is more likely to increase foreign technology adoption at higher levels of foreign tariffs. This suggests that real depreciations may help offsetting the negative effect of foreign tariffs on export competitiveness. Importantly, the estimates for the other variables are not significantly affected when tariffs are included.

Finally, we study if annual changes in the RER have significant effects on the use of foreign technology licenses. In Table 7 we present the basic results for the probability of licensing using the annual change in the RER instead of the 5-year or 3-year changes. The estimates are qualitatively similar to what we obtain with longer changes. We still observe that an increase in the change in the RER increases the probability of licensing in more productive and larger plants and that the effect of productivity and size is not linear. Although the estimate for the interaction between the change in the RER and the export dummy is positive, it is no longer statistically significant. This suggests that exporters do not necessarily respond to short-run changes in the RER when making import decisions of technology.

Summarizing, the effect of real depreciations on the probability of acquiring foreign technologies is robust to the inclusion of additional control variables at the sector level and to the way the change in the RER is measured. 


\section{CONCLUSIONS}

This paper used plant-level data from the manufacturing sector of Chile to investigate how changes in the RER affect the decision to purchase foreign technologies through licensing. Most recent models in the international trade literature assume exogenous productivity (Melitz, 2003; Bernard et al., 2003) and do not explicitly consider the possibility of technology upgrading investments with the purpose of competing in international markets. However, as formalized in recent papers (e.g., Bustos, 2011), changes in export competitiveness may affect innovation among firms. In this framework, firms may decide to acquire new technologies in order to improve their chances of staying in international markets. Moreover, in this type of models, the effect of changes in export competitiveness is potentially heterogeneous across firms.

This paper used exogenous changes in the RER to shed light on these heterogeneous effects. In addition to differences in size and productivity across firms, we also looked at how industry characteristics -comparative advantage and financial needs- affect firms' responses regarding foreign technology acquisition. Our results suggest that RER depreciations increase foreign technology adoption mostly for exporters, as we expected. We also found that as plants' productivity and size increase, the effect of a real depreciation on technology licensing is larger, but the effect is not linear. The highest impact of changes in export competitiveness is for plants in the intermediate range of productivity and size distribution, similar to previous evidence for Argentinean firms provided by Bustos (2011).

Our results are robust to alternative specifications, different definitions of changes in the RER, and the inclusion of other control variables. In particular, we find that several measures of the incidence of licensing activity in the same sector are positively correlated with foreign technology adoption at the firm level. Although this is an interesting result, more work is needed to uncover the causal effect of these potentially informational spillovers. An alternative interpretation can be that we are capturing unobserved industry-specific shocks in the costs of foreign technologies. In general, an increase in RER causes a raise in export competitiveness, but it may also increase the cost of importing foreign technologies through 
licenses. With the data at hand, we cannot separate both effects. This can be an interesting question for future research.

The evidence in this paper can potentially have important policy implications for developing countries aiming to increase innovation and productivity. International markets are seen, in general, as an important stimulus, or channel, for upgrading technologies in the domestic economy. However, as this paper shows, the effects of changes in RERs are heterogeneous. Small and low-productivity firms are less likely to upgrade technologies even when they face positive shocks. In such a case, complementary polices may be needed to increases innovation and productivity in these firms.

\section{REFERENCES}

Alvarez, R., Crespi, G. and Ramos, J. (2002). "The Impact of Licenses on a 'Late Starter' LDC: Chile in the 1990s." World Development 30(8), 1445-1460.

Alvarez, R. and López, R. A. (2005). "Exporting and Performance: Evidence from Chilean Plants." Canadian Journal of Economics 38(4), 1384-1400.

Alvarez, R. and López, R. A. (2009). "Skill Upgrading and the Real Exchange Rate," The World Economy 32(8), 1165-1179.

Anderson, J. E. and Neary, P. (2005). Measuring the Restrictiveness of International Trade Policy. Cambridge, MA: MIT Press.

Arora, A. (1996). "Contracting for Tacit Knowledge: The Provision of Technical Services in Technology Licensing Contracts." Journal of Development Economics 50(2), 233-256.

Bernard, A. B., Eaton, J., Jensen, J. B. and Kortum, S. S. (2003). "Plants and Productivity in International Trade." American Economic Review 93(4), 1268-1290.

Bernard, A. B. and Jensen, J. B. (2004). "Why Some Firms Export." Review of Economics and Statistics 86(2), 561-569. 
Bhattacharya, G. (1985). "Technology Transfer, Licensing and the Speed of Endogenous Technological Change." Journal of Economic Dynamics and Control 9(4), 423-456.

Bustos, P. (2011). "Trade Liberalization, Exports, and Technology Upgrading: Evidence on the Impact of MERCOSUR on Argentinean Firms." American Economic Review 101(1), 304-340.

Dahlman, C. and Westphal, L. (1982). "Technological Effort in Industrial Development - An Interpretative Survey of Recent Research." In F. Stewart and J. James (eds.), The Economics of New Technology in Developing Countries (pp. 105-137). London: Frances Pinter.

Fitzgerald, D. and Haller, S. (2012). "Exporters and Shocks." Stanford University (Stanford, CA) and The Economic and Social Research Institute (Dublin, Ireland).

Giannitsis, T. (1991). "Licensing in a Newly Industrializing Country: The Case of Greek Manufacturing." World Development 19(4), 349-362.

Greenaway, D., Kneller, R. and Zhang, X. (2010a). "Exchange Rate Uncertainty and Export Decisions in the UK," Journal of Economic Integration 24(4), 734-753.

Greenaway, D., Kneller, R. and Zhang, X. (2010b). "The Effect of Exchange Rates on Firm Exports: The Role of Imported Intermediate Inputs." The World Economy 33(8), 961-986.

Greenaway, D., Kneller, R. and Zhang, X. (2012). "The Effect of Exchange Rates on Firm Exports and the Role of FDI." Review of World Economics 148(3), 425-447.

Hoekman, B. and Javorcik, B. S. (2006). "Lessons from Empirical Research on International Technology Diffusion Through Trade and Foreign Direct Investment." In B. Hoekman and B. S. Javorcik (Eds.), Global Integration and Technology Transfer (pp. 1-26). New York, N.Y.: Palgrave.

Kandilov, I. and Leblebicioğlu, A. (2011). "The Impact of Exchange Rate Volatility on Plant-Level Investment: Evidence from Colombia." Journal of Development Economics 94(2): 220-230.

Katrak, H. (1997). "Developing Countries' Imports of Technology, In-House Technological Capabilities and Efforts: An Analysis of the Indian Experience." Journal of Development Economics 53(1), 67-83. 
Kiyota, K. and Okazaki, T. (2005). "Foreign Technology Acquisition Policy and Firm Performance in Japan, 1957-1970: Micro-aspects of Industrial Policy." International Journal of Industrial Organization 23(7-8), 563-586.

Kokko, A. and Blomström, M. (1995) "Policies to Encourage Inflows of Technology through Foreign Multinationals." World Development 23(3), 459-468.

Lileeva, A. and Trefler, D. (2010). "Improved Access to Foreign Markets Raises Plant-Level Productivity... for Some Plants." Quarterly Journal of Economics 125(3), 1051-1099.

López, R. A. (2009). "Do Firms Increase Productivity in Order to Become Exporters?" Oxford Bulletin of Economics and Statistics 71(5), 621-642.

Melitz, M. (2003). “The Impact of Trade on Intra-Industry Reallocations and Aggregate Industry Productivity,” Econometrica, 71(6), 1695-1725.

Montalvo, J. G. and Yafeh, Y. (1994). "A Microeconometric Analysis of Technology Transfer: The Case of Licensing Agreements of Japanese Firms." International Journal of Industrial Organization 12(2), 227-244.

Mytelka, L. K. (1978). "Licensing and Technology Dependence in the Andean Group." World Development 6(4), 447-459.

Pack, H. (2006). "Econometric versus Case Study Approaches to Technology Transfer." In B. Hoekman, and B. S. Javorcik (Eds.), Global Integration and Technology Transfer (pp. 29-50). New York, N.Y.: Palgrave.

Rajan, R. G. and Zingales, L. (1998). "Financial Development and Growth." American Economic Review 88(3), 559-586.

Smith, P. J. (2001). "How do Foreign Patent Rights Affect U.S. Exports, Affiliate Sales, and Licenses? Journal of International Economics 55(2), 411-439.

Vishwasrao, S. and Bosshardt, W. (2001). "Foreign Ownership and Technology Adoption: Evidence from Indian firms." Journal of Development Economics 65(2), 367-387. 
Westphal, L. E. (1982). "Fostering Technological Mastery by Means of Selective Infant-industry Protection." In M. Syrquin, \& S. Teitel (Eds.), Trade, Stability, Technology, and Equity in Latin America (pp. 255-279). New York, NY: Academic Press.

Yasar, M. and Paul, C. J. M. (2007). "International Linkages and Productivity at the Plant Level: Foreign Direct Investment, Exports, Imports and Licensing." Journal of International Economics 71(2), 373-388. 


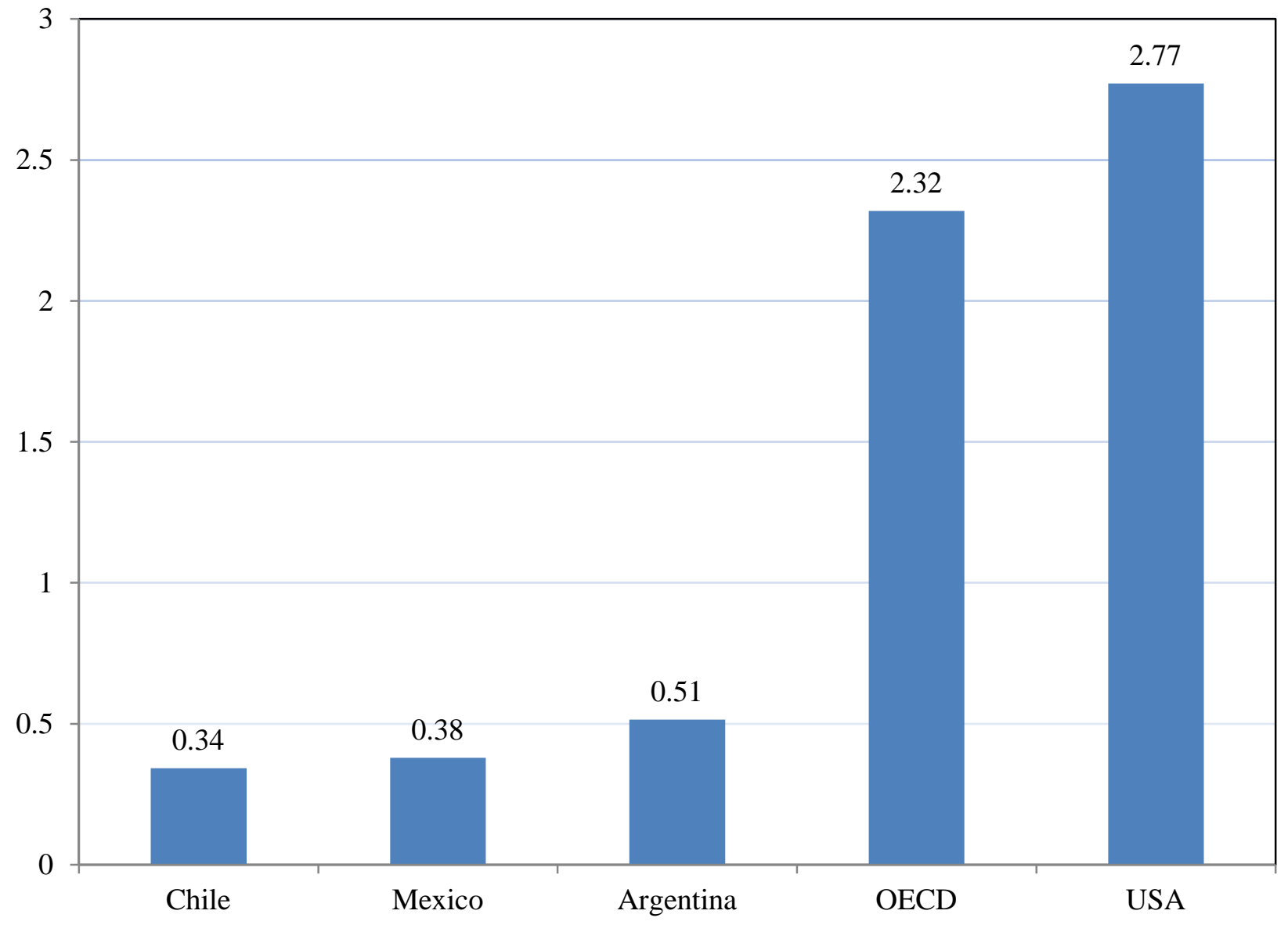

Figure 1: Expenditure on R\&D (\% of the GDP, average 2007-2008) (Source: OECD) 


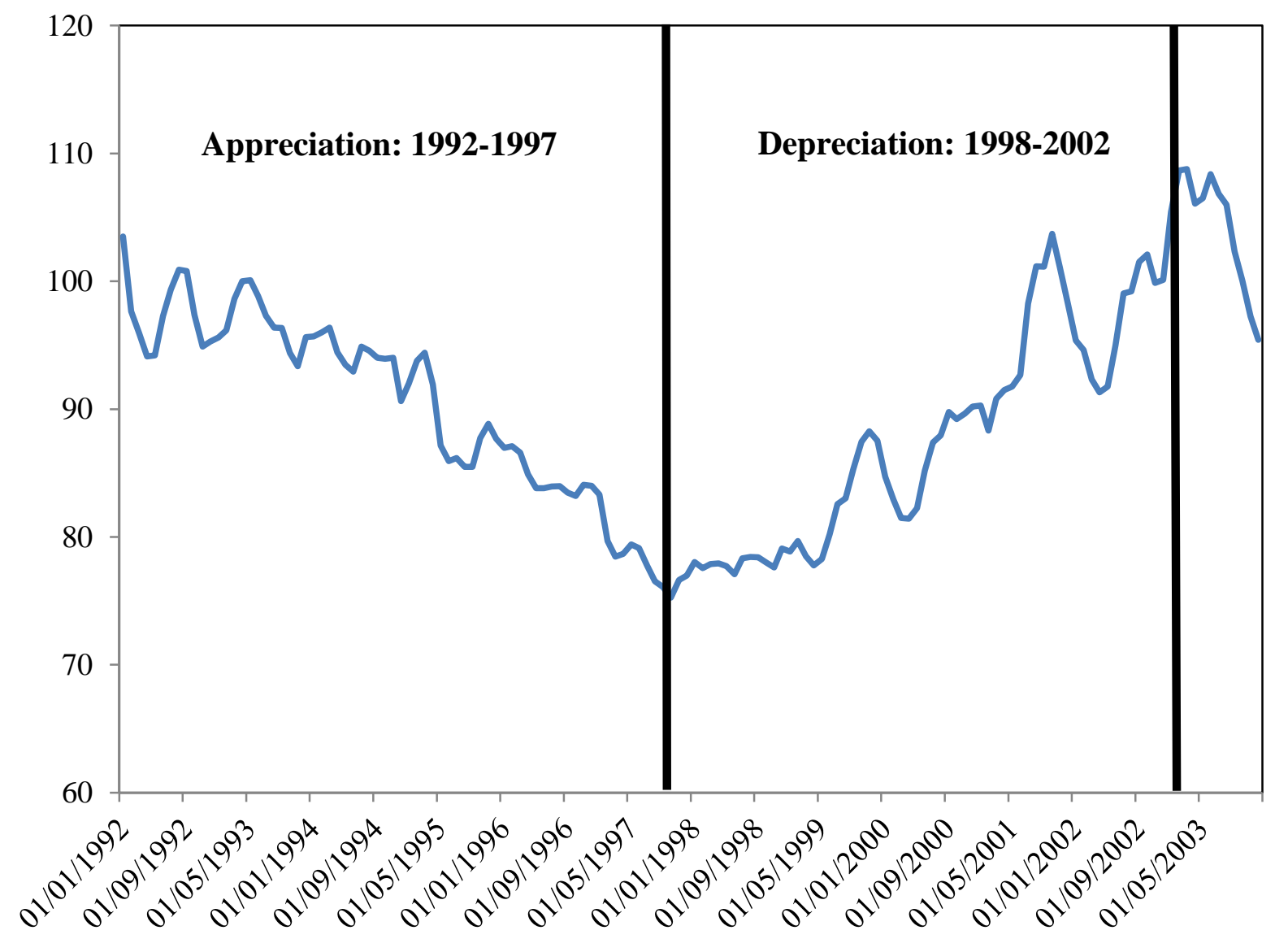

Figure 2: Evolution of the RER - 1992-2003

(Source: Central Bank of Chile) 
Table 1: Royalties and License Fees Payments (Percentage of GDP)

\begin{tabular}{cccc}
\hline & \multicolumn{4}{l}{ Chile } & Latin America & OECD \\
\hline $1975-1980$ & 0.10 & 0.06 & 0.08 \\
$1981-1990$ & 0.14 & 0.09 & 0.09 \\
$1991-2000$ & 0.19 & 0.11 & 0.20 \\
& & & \\
$2001-2010$ & 0.30 & 0.14 & 0.33 \\
$1975-2010$ & 0.19 & 0.11 & 0.19 \\
\hline
\end{tabular}

Source: World Development Indicators. 
Table 2: Number of Plants and Licensees

\begin{tabular}{lcccccc}
\hline & \multirow{2}{*}{$\begin{array}{c}\text { No. of Plants } \\
\text { \% of Licensees }\end{array}$} & \multicolumn{2}{c}{ \% of Exporters Among: } & \multicolumn{2}{c}{ Employment (No. Workers) } \\
\cline { 3 - 7 } & & & Non-licensees & Licensees & Non-licensees & Licensees \\
\hline 1993 & 4,182 & 5.9 & 19.2 & 56.7 & 74 & 273 \\
1994 & 4,244 & 5.3 & 20.8 & 56.8 & 78 & 248 \\
1995 & 4,241 & 5.7 & 21.0 & 57.4 & 75 & 266 \\
1996 & 4,207 & 6.1 & 21.1 & 59.9 & 75 & 254 \\
1997 & 4,291 & 5.3 & 20.5 & 66.8 & 74 & 264 \\
1998 & 3,931 & 5.9 & 20.5 & 60.0 & 73 & 259 \\
1999 & 3,565 & 5.5 & 18.8 & 59.9 & 73 & 258 \\
2000 & 3,428 & 5.9 & 17.5 & 53.7 & 68 & 211 \\
2001 & 3,376 & 5.3 & 19.0 & 52.2 & 67 & 232 \\
2002 & 3,508 & 4.8 & 19.4 & 56.5 & 70 & 226 \\
Average & 3,897 & 5.6 & 19.8 & 58.0 & 73 & 249 \\
\hline
\end{tabular}


Table 3: Summary Statistics

\begin{tabular}{lccccc}
\hline Variable & Obs. & Mean & Std. Dev. & Min & Max \\
\hline Licenses & 38,973 & 0.06 & 0.23 & 0.00 & 1.00 \\
Productivity & 38,973 & $10,044.32$ & $28,688.62$ & 69.2 & $2,249,509$ \\
Log(Productivity) & 38,973 & 8.63 & 0.92 & 4.24 & 14.6 \\
Exporter Dummy & 38,973 & 0.22 & 0.41 & 0.00 & 1.00 \\
Employment & 38,973 & 82.95 & 159.4 & 2 & 3663 \\
Log(Employment) & 38,973 & 3.71 & 1.06 & 1.39 & 8.20 \\
Financial Dependence & 38,973 & 0.27 & 0.29 & -0.15 & 1.14 \\
Comparative Advantage & 38,973 & 1.51 & 1.96 & 0.023 & 18.27 \\
5-year Change in RER & 38,973 & -0.10 & 0.14 & -0.21 & 0.24 \\
3-year Change in RER & 38,973 & -0.04 & 0.13 & -0.17 & 0.23 \\
\hline
\end{tabular}


Table 4: Basic Results with 5-Year and 3-Year Changes in the RER

\begin{tabular}{|c|c|c|c|c|}
\hline \multirow{3}{*}{ Licensee Year Before } & $(1)$ & $(2)$ & $(3)$ & $(4)$ \\
\hline & \multicolumn{2}{|c|}{ 5-Year Change RER } & \multicolumn{2}{|c|}{ 3-Year Change RER } \\
\hline & $\begin{array}{c}0.121 * * * \\
(0.006)\end{array}$ & $\begin{array}{c}0.121^{* * *} \\
(0.006)\end{array}$ & $\begin{array}{c}0.121 * * * \\
(0.006)\end{array}$ & $\begin{array}{c}0.121^{* * *} \\
(0.006)\end{array}$ \\
\hline Productivity & $\begin{array}{l}-0.006 \\
(0.022)\end{array}$ & $\begin{array}{c}-0.006 \\
(0.022)\end{array}$ & $\begin{array}{l}-0.029 \\
(0.021)\end{array}$ & $\begin{array}{c}-0.029 \\
(0.021)\end{array}$ \\
\hline$(\text { Productivity) })^{2}$ & $\begin{array}{c}0.001 \\
(0.001)\end{array}$ & $\begin{array}{c}0.001 \\
(0.001)\end{array}$ & $\begin{array}{l}0.002 * \\
(0.001)\end{array}$ & $\begin{array}{l}0.002^{*} \\
(0.001)\end{array}$ \\
\hline Size & $\begin{array}{c}-0.040 * * * \\
(0.015)\end{array}$ & $\begin{array}{c}-0.040^{* * *} \\
(0.015)\end{array}$ & $\begin{array}{c}-0.046 * * * \\
(0.016)\end{array}$ & $\begin{array}{c}-0.046^{* * *} \\
(0.016)\end{array}$ \\
\hline$(\text { Size })^{2}$ & $\begin{array}{c}0.006^{* * *} \\
(0.002)\end{array}$ & $\begin{array}{c}0.006 * * * \\
(0.002)\end{array}$ & $\begin{array}{c}0.007 * * * \\
(0.002)\end{array}$ & $\begin{array}{c}0.007 * * * \\
(0.002)\end{array}$ \\
\hline Export Dummy & $\begin{array}{c}0.007 \\
(0.005)\end{array}$ & $\begin{array}{c}0.007 \\
(0.005)\end{array}$ & $\begin{array}{c}0.004 \\
(0.005)\end{array}$ & $\begin{array}{c}0.004 \\
(0.005)\end{array}$ \\
\hline DRER * Productivity & $\begin{array}{c}0.431^{* * *} \\
(0.089)\end{array}$ & $\begin{array}{c}0.432 * * * \\
(0.090)\end{array}$ & $\begin{array}{c}0.475^{* * *} \\
(0.097)\end{array}$ & $\begin{array}{c}0.468 * * * \\
(0.098)\end{array}$ \\
\hline DRER * (Productivity) $)^{2}$ & $\begin{array}{c}-0.026^{* * *} \\
(0.005)\end{array}$ & $\begin{array}{c}-0.026^{* * *} \\
(0.005)\end{array}$ & $\begin{array}{c}-0.029 * * * \\
(0.005)\end{array}$ & $\begin{array}{c}-0.028^{* * *} \\
(0.005)\end{array}$ \\
\hline DRER * Size & $\begin{array}{l}0.070^{*} \\
(0.042)\end{array}$ & $\begin{array}{l}0.070 * \\
(0.042)\end{array}$ & $\begin{array}{c}0.103^{* *} \\
(0.048)\end{array}$ & $\begin{array}{c}0.102 * * \\
(0.048)\end{array}$ \\
\hline DRER * $(\text { Size })^{2}$ & $\begin{array}{l}-0.009 * \\
(0.005)\end{array}$ & $\begin{array}{l}-0.010^{*} \\
(0.005)\end{array}$ & $\begin{array}{c}-0.013 * * \\
(0.006)\end{array}$ & $\begin{array}{c}-0.013 * * \\
(0.006)\end{array}$ \\
\hline DRER * Export Dummy & $\begin{array}{c}0.058 * * * \\
(0.021)\end{array}$ & $\begin{array}{c}0.058^{* * * *} \\
(0.021)\end{array}$ & $\begin{array}{c}0.063 * * * \\
(0.023)\end{array}$ & $\begin{array}{c}0.063 * * * \\
(0.023)\end{array}$ \\
\hline DRER * Ext. Fin. Dep. & & $\begin{array}{c}0.002 \\
(0.027)\end{array}$ & & $\begin{array}{c}0.002 \\
(0.029)\end{array}$ \\
\hline DRER * Comp. Adv. & & $\begin{array}{c}0.000 \\
(0.000)\end{array}$ & & $\begin{array}{l}-0.000 \\
(0.000)\end{array}$ \\
\hline Constant & $\begin{array}{c}0.353 * * * \\
(0.100)\end{array}$ & $\begin{array}{c}0.354 * * * \\
(0.100)\end{array}$ & $\begin{array}{c}0.516 * * * \\
(0.109)\end{array}$ & $\begin{array}{c}0.510^{* * *} \\
(0.110)\end{array}$ \\
\hline Observations & 38,973 & 38,973 & 38,973 & 38,973 \\
\hline R-Squared (within) & 0.018 & 0.018 & 0.018 & 0.018 \\
\hline $\begin{array}{l}\text { Dependent variable: Dun } \\
\text { licenses. Standard error } \\
\text { Productivity: Value added } \\
\text { size are in logs. Productivi } \\
\text { and vear fixed effects were }\end{array}$ & qual to on & if the plan & uses foreig & $\begin{array}{l}\text { technology } \\
\quad * \quad \mathrm{p}<0.1 \text {. } \\
\text { uctivity and } \\
\text { e year. Plant }\end{array}$ \\
\hline
\end{tabular}


Table 5: Results with Additional Controls

\begin{tabular}{|c|c|c|c|c|c|c|}
\hline & (1) & $(2)$ & (3) & (4) & (5) & (6) \\
\hline & \multicolumn{3}{|c|}{ 5-Year Change RER } & \multicolumn{3}{|c|}{ 3-Year Change RER } \\
\hline & $0.119 * * *$ & $0.120 * * *$ & $0.120 * * *$ & $0.119 * * *$ & $0.120 * * *$ & $0.120 * * *$ \\
\hline Licensee Year Before & $(0.006)$ & $(0.006)$ & $(0.006)$ & $(0.006)$ & $(0.006)$ & $(0.006)$ \\
\hline \multirow[t]{2}{*}{ Productivity } & -0.012 & -0.008 & -0.009 & -0.034 & -0.032 & -0.032 \\
\hline & $(0.022)$ & $(0.022)$ & $(0.022)$ & $(0.021)$ & $(0.021)$ & $(0.021)$ \\
\hline \multirow[t]{2}{*}{$\left(\right.$ Productivity) ${ }^{2}$} & 0.001 & 0.001 & 0.001 & $0.002^{* *}$ & $0.002 *$ & $0.002 *$ \\
\hline & $(0.001)$ & $(0.001)$ & $(0.001)$ & $(0.001)$ & $(0.001)$ & $(0.001)$ \\
\hline \multirow[t]{2}{*}{ Export Dummy } & 0.007 & 0.007 & 0.007 & 0.004 & 0.004 & 0.004 \\
\hline & $(0.005)$ & $(0.005)$ & $(0.005)$ & $(0.005)$ & $(0.005)$ & $(0.005)$ \\
\hline \multirow[t]{2}{*}{ Size } & $-0.041 * * *$ & $-0.041 * * *$ & $-0.042 * * *$ & $-0.046 * * *$ & $-0.046 * * *$ & $-0.047 * * *$ \\
\hline & $(0.015)$ & $(0.015)$ & $(0.015)$ & $(0.016)$ & $(0.016)$ & $(0.016)$ \\
\hline \multirow{2}{*}{$(\mathrm{Size})^{2}$} & $0.006 * * *$ & $0.006 * * *$ & $0.006 * * *$ & $0.007 * * *$ & $0.007 * * *$ & $0.007 * * *$ \\
\hline & $(0.002)$ & $(0.002)$ & $(0.002)$ & $(0.002)$ & $(0.002)$ & $(0.002)$ \\
\hline \multirow[t]{2}{*}{ DRER * Productivity } & $0.412 * * *$ & $0.435 * * *$ & $0.441^{* * *}$ & $0.448 * * *$ & $0.465 * * *$ & $0.473 * * *$ \\
\hline & $(0.090)$ & $(0.090)$ & $(0.090)$ & $(0.098)$ & $(0.098)$ & $(0.098)$ \\
\hline \multirow[t]{2}{*}{ DRER * (Productivity) $)^{2}$} & $-0.025 * * *$ & $-0.026 * * *$ & $-0.026 * * *$ & $-0.027 * * *$ & $-0.028 * * *$ & $-0.028 * * *$ \\
\hline & $(0.005)$ & $(0.005)$ & $(0.005)$ & $(0.005)$ & $(0.005)$ & $(0.005)$ \\
\hline \multirow[t]{2}{*}{ DRER * Export Dummy } & $0.058 * * *$ & $0.055^{* * *}$ & $0.056 * * *$ & $0.062 * * *$ & $0.061 * * *$ & $0.063 * * *$ \\
\hline & $(0.021)$ & $(0.021)$ & $(0.021)$ & $(0.023)$ & $(0.023)$ & $(0.023)$ \\
\hline \multirow[t]{2}{*}{ DRER * Size } & 0.062 & 0.069 & 0.067 & $0.094 *$ & $0.101 * *$ & $0.100 * *$ \\
\hline & $(0.042)$ & $(0.042)$ & $(0.042)$ & $(0.048)$ & $(0.048)$ & $(0.048)$ \\
\hline \multirow[t]{2}{*}{ DRER * $(\text { Size })^{2}$} & $-0.008^{*}$ & $-0.009 *$ & $-0.009 *$ & $-0.012 * *$ & $-0.013 * *$ & $-0.013^{* *}$ \\
\hline & $(0.005)$ & $(0.005)$ & $(0.005)$ & $(0.006)$ & $(0.006)$ & $(0.006)$ \\
\hline \multirow[t]{2}{*}{ DRER * Ext. Fin. Dep. } & 0.026 & -0.019 & -0.017 & 0.028 & -0.019 & -0.016 \\
\hline & $(0.027)$ & $(0.027)$ & $(0.027)$ & $(0.029)$ & $(0.029)$ & $(0.029)$ \\
\hline \multirow[t]{2}{*}{ DRER * Comp. Adv. } & 0.000 & 0.000 & -0.000 & 0.000 & -0.000 & -0.000 \\
\hline & $(0.000)$ & $(0.000)$ & $(0.000)$ & $(0.000)$ & $(0.000)$ & $(0.000)$ \\
\hline \multirow[t]{2}{*}{ Share Licensees } & $0.594 * * *$ & & & $0.594^{* * *}$ & & \\
\hline & $(0.048)$ & & & $(0.048)$ & & \\
\hline \multirow[t]{2}{*}{ Share Foreign } & -0.083 & & & -0.080 & & \\
\hline & $(0.061)$ & & & $(0.061)$ & & \\
\hline \multirow[t]{2}{*}{ Share Licensees in VA } & & $0.076 * * *$ & & & $0.076^{* * *}$ & \\
\hline & & $(0.010)$ & & & $(0.010)$ & \\
\hline \multirow[t]{2}{*}{ Share Foreign in VA } & & -0.004 & & & -0.000 & \\
\hline & & $(0.015)$ & & & $(0.016)$ & \\
\hline \multirow[t]{2}{*}{ Share Licensees in L } & & & $0.149 * * *$ & & & $0.149 * * *$ \\
\hline & & & $(0.017)$ & & & $(0.017)$ \\
\hline \multirow[t]{2}{*}{ Share Foreign in L } & & & 0.019 & & & 0.027 \\
\hline & & & $(0.028)$ & & & $(0.028)$ \\
\hline \multirow[t]{2}{*}{ Constant } & $0.341^{* * *}$ & $0.346^{* * *}$ & $0.344 * * *$ & $0.491 * * *$ & $0.501 * * *$ & $0.501 * * *$ \\
\hline & $(0.100)$ & $(0.100)$ & $(0.100)$ & $(0.110)$ & $(0.110)$ & $(0.110)$ \\
\hline Observations & 38,973 & 38,973 & 38,973 & 38,973 & 38,973 & 38,973 \\
\hline R-Squared (within) & 0.023 & 0.020 & 0.020 & 0.023 & 0.019 & 0.020 \\
\hline \multicolumn{7}{|c|}{$\begin{array}{l}\text { Dependent variable: Dummy equal to one if the plant uses foreign technology licenses. Standard errors in parentheses. } \\
\mathrm{p}<0.01, * * \mathrm{p}<0.05, * \mathrm{p}<0.1 \text {. Productivity: Value added per worker; Size: Number of employees. Productivity and size are in } \\
\text { logs. Productivity, Size, and the Export Dummy are lagged one year. Share Licensees, Share Licensees in VA and Share } \\
\text { Licensees in L correspond to the share of plants that use licenses in the total number of plants, total value added and tota } \\
\text { employment in each 3-digit sector. Share Foreign, Share Foreign in VA and Share Foreign in L correspond to the share of } \\
\text { plants with foreign ownership in the total number of plants, total value added and total employment in each 3-digit sector. Plan } \\
\text { and year fixed effects were included. }\end{array}$} \\
\hline
\end{tabular}


Table 6: Results with Additional Controls and Tariffs

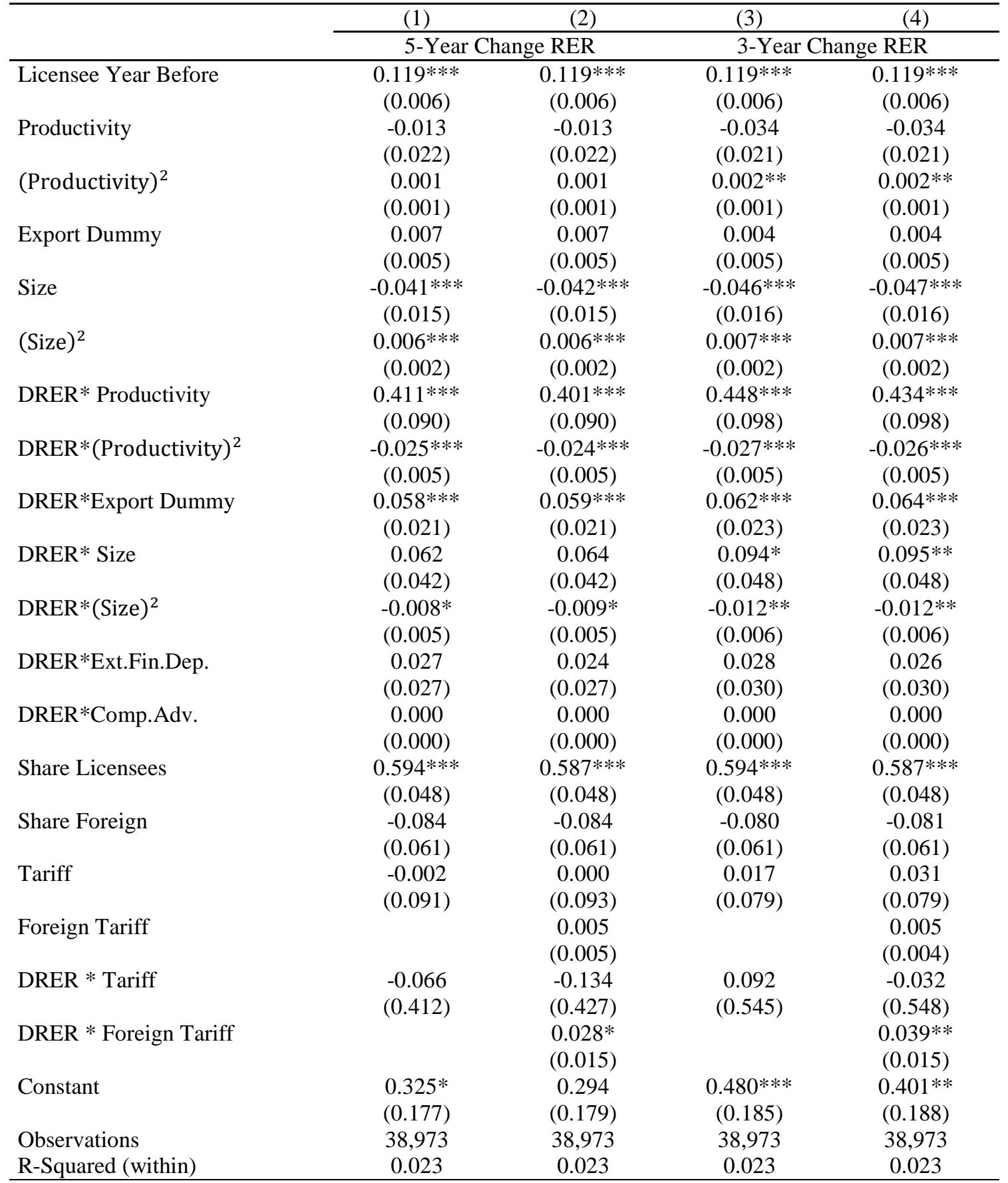

Dependent variable: Dummy equal to one if the plant uses foreign technology licenses. Standard errors in parentheses. ${ }^{* * *} \mathrm{p}<0.01,{ }^{* *} \mathrm{p}<0.05$, ${ }^{*} \mathrm{p}<0.1$. Productivity: Value added per worker; Size: Number of employees. Productivity and size are in logs. Productivity, Size, and the Export Dummy are lagged one year. Share Licensees is to the share of plants that use licenses in the total number of plants in each 3digit sector. Share Foreign is the share of plants with foreign ownership in the total number of plants in each 3-digit sector. Plant and year fixed effects were included. 
Table 7: Basic Model with Annual Changes in RER

\begin{tabular}{|c|c|c|}
\hline & $(1)$ & $(2)$ \\
\hline Licensee Year Before & $\begin{array}{c}0.122^{* * *} \\
(0.006)\end{array}$ & $\begin{array}{c}0.122^{* * * *} \\
(0.006)\end{array}$ \\
\hline Productivity & $\begin{array}{c}-0.037 * \\
(0.021)\end{array}$ & $\begin{array}{c}-0.036^{*} \\
(0.021)\end{array}$ \\
\hline (Productivity) $^{2}$ & $\begin{array}{c}0.003^{* *} \\
(0.001)\end{array}$ & $\begin{array}{c}0.002^{* *} \\
(0.001)\end{array}$ \\
\hline Export Dummy & $\begin{array}{c}0.006 \\
(0.005)\end{array}$ & $\begin{array}{c}0.006 \\
(0.005)\end{array}$ \\
\hline Size & $\begin{array}{c}-0.046^{* * *} \\
(0.016)\end{array}$ & $\begin{array}{c}-0.046^{* * *} \\
(0.016)\end{array}$ \\
\hline$(\text { Size })^{2}$ & $\begin{array}{c}0.007 * * * \\
(0.002)\end{array}$ & $\begin{array}{c}0.007 * * * \\
(0.002)\end{array}$ \\
\hline DRER* Productivity & $\begin{array}{c}0.588^{* *} \\
(0.235)\end{array}$ & $\begin{array}{c}0.535^{* *} \\
(0.237)\end{array}$ \\
\hline DRER* (Productivity) $^{2}$ & $\begin{array}{c}-0.037^{* * *} \\
(0.013)\end{array}$ & $\begin{array}{c}-0.034^{* * *} \\
(0.013)\end{array}$ \\
\hline DRER* Export Dummy & $\begin{array}{c}0.084 \\
(0.054)\end{array}$ & $\begin{array}{c}0.084 \\
(0.054)\end{array}$ \\
\hline DRER* Size & $\begin{array}{c}0.240^{* *} \\
(0.116)\end{array}$ & $\begin{array}{c}0.230 * * \\
(0.117)\end{array}$ \\
\hline $\operatorname{DRER}^{*}(\text { Size })^{2}$ & $\begin{array}{c}-0.028 * * \\
(0.014)\end{array}$ & $\begin{array}{l}-0.027^{*} \\
(0.014)\end{array}$ \\
\hline DRER* Ext. Fin. Dep. & & $\begin{array}{c}0.016 \\
(0.069)\end{array}$ \\
\hline DRER * Comp. Adv. & & $\begin{array}{c}-0.000 \\
(0.000)\end{array}$ \\
\hline Constant & $\begin{array}{c}0.270^{* * *} \\
(0.098)\end{array}$ & $\begin{array}{c}0.264^{* * *} \\
(0.098)\end{array}$ \\
\hline Observations & 38,973 & 38,973 \\
\hline R-Squared (within) & 0.017 & 0.017 \\
\hline $\begin{array}{l}\text { Dependent variable: Du } \\
\text { foreign technology licens } \\
\mathrm{p}<0.01, * * \quad \mathrm{p}<0.05,{ }^{*} \\
\text { worker; Size: Number o } \\
\text { in logs. Productivity, Siz } \\
\text { one year. Plant and year }\end{array}$ & $\begin{array}{l}\text { ul to one } \\
\text { ard errors in } \\
\text { oductivity: } \\
\text { es. Product } \\
\text { e Export D } \\
\text { ts were inc }\end{array}$ & $\begin{array}{l}\text { e plant uses } \\
\text { entheses. } * * * \\
\text { e added per } \\
\text { and size are } \\
\text { y are lagged } \\
\text {. }\end{array}$ \\
\hline
\end{tabular}

